JEL Classification: E21, E22, E27, E59

Keywords: DSGE models, financial accelerator, financial frictions

\title{
Survey of Research on Financial Sector Modeling within DSGE Models: What Central Banks Can Learn from It
}

\author{
František BRÁZDIK—Czech National Bank, Prague (frantisek.brazdik@cnb.cz) \\ Michal HLAVÁČEK-Czech National Bank and Institute of Economic Studies, Faculty of Social \\ Sciences, Charles University, Prague (michal.hlavacek@cnb.cz) \\ Aleš MARŠÁL_-Institute of Economic Studies, Faculty of Social Sciences, Charles University, \\ Prague and Institute of Information Theory and Automation, Czech Academy \\ of Science, Prague (ales.marsal@seznam.cz), corresponding author
}

\begin{abstract}
This survey gives insight into the ongoing research in financial frictions modeling. The recent financial turmoil has fueled interest in operationalizing financial frictions concepts. The rapid growth of the literature on financial frictions motivates this review. The empirical facts that motivate the inclusion of financial frictions are surveyed. This survey provides a description of the basic approaches for introducing financial frictions into dynamic stochastic general equilibrium models. The significance and empirical identification of the financial accelerator effect is then discussed. The role of financial frictions models in CNB monetary and macroprudential policy is described. It is concluded that given the heterogeneity of the approaches to financial frictions it is beneficial for the conduct of monetary policy to focus on the development of satellite approaches. DSGE models with financial frictions used to generate stress-testing scenarios could complement current stress-testing practice, but are not able to replace it.
\end{abstract}

\section{Introduction}

In this work, literature focusing on financial frictions in the framework of general equilibrium macroeconomic models is reviewed. Dynamic stochastic general equilibrium (DSGE) models have become a popular tool. The popularity of DSGE models originates from the use of microeconomic foundations, which allows for more detailed and structured analysis of the origins and evolution of observed business cycles than econometric models can provide.

Despite the stage of theoretical development, the standard DSGE models do not include the interaction of financial markets with the rest of the economy. Mainstream theory and applications assume smooth and perfect functioning of financial markets. These assumptions allow for abstraction from the constraints present in markets and make market arrangements less complex. Due to this abstraction, the implications of market imperfections for business cycles are included in standard models only implicitly or insufficiently, or are even ignored.

\footnotetext{
* This research was supported by Czech National Bank Research Project C2/10. The views expressed in this paper are not necessarily those of the Czech National Bank. We are thankful for comments from referees and seminar participants at the Czech National Bank. Aleš Maršál was supported by GAČR, grant no. P402-12-1993.
} 
The origins of investigation of the influence of the financial markets on business cycles can be found in Bernanke and Gertler (1989), long before the recent financial crisis erupted. Their interest led to the creation of models that distinguish the sources of capital for funding the investment projects of economic agents. Further development led to the construction of models with constraints on the amount of credit available for investment.

The recent financial crisis has sparked interest in financial rigidities and also an increase in the number of papers focusing on theories of investment behavior, the optimal structure of financing, and asymmetric information.

The recent interest in financial frictions has also sparked interest in surveying the actual literature (e.g. Research Task Force Working Group on the Transmission Channels between the Financial and Real Sectors of the Basel Committee on Banking Supervision, 2011; Brzoza-Brzezina, Kolasa, and Makarski, 2011). However, these surveys are either not focused on DSGE modeling or contain no description of its application. Therefore, in this survey the framework used in the Czech National Bank (CNB) for macroprudential analysis is described.

The following section presents the motivation for models of financial frictions stemming from business cycle properties. In the third section, modeling of the external finance premium is reviewed. In the fourth section, models with credit constraints are presented. In the fifth section, the specification of the role of financial intermediaries in financial markets is described. In the sixth section, the potential use of models with financial frictions in practical monetary and macroprudential policy making is discussed.

\section{Motivation}

The most apparent property of economic output observable in the data is its asymmetric fluctuations around the trajectory with a positive trend.

Although a decrease has been identified, the amplitude of the observed fluctuations is still considered significant (Bernanke and Gertler, 1995; Kocherlakota, 2000). Also, a decrease in the growth rate below its long-term average is usually followed by a significant period of slower growth, as documented by Falk (1986) and Acemoglu and Scott (1997).

Standard DSGE models are still not able to reproduce the characteristics of economic fluctuations without the use of extensive and persistent shocks. Empirical studies focused on the identification of shocks conclude that extensive and persistent shocks cannot easily be found and explained (e.g. Cochrane, 1994; Summers, 1986). Even current studies are aware of these problems. For example, Del Negro et al. (2005), discussing the results of estimating their model, write that "the high persistence of many of the exogenous processes raises concerns about the ability of the DSGE model to generate endogenous propagation mechanisms", while Chari et al. (2009) have argued that estimated wage mark-up shocks, which affect the bargaining power of unions in a monopolistically competitive labor market, are too large to have a credible structural interpretation. Therefore, the reproduction of business cycle properties by models is still motivating the search for a mechanism able to transform shocks in a specific sector of the economy into extensive, persistent, and asymmetric fluctuations. 
Notwithstanding the advances in reproducing business cycle properties, the identification of shocks that drive cycles has come into the focus of the recent literature (e.g. Benk et al., 2005; Christiano, Eichenbaum, and Vigfusson, 2006; Jermann and Quadrini, 2009). The identification of shocks is based on a combination of econometric methods and DSGE models. The impulse response allows one to evaluate the mechanisms of DSGE models in light of the extent and persistence of the deviation. Empirical papers (e.g. Reichlin, 2004) criticize the standard DSGE framework for problems with modeling the characteristics of business cycles, e.g. its inability to explain the observed degree of macroeconomic volatility or why financial markets aggravate the consequences and persistence of shocks originating in the real economy. These problems motivate the introduction of frictions originating in financial markets into DSGE models.

The standard models assume that representative economic agents operating in perfect financial markets have immediate access to an unlimited amount of funding. Therefore, rigidities and constraints that limit the accessibility of funding are introduced. The mechanisms that can amplify shocks from the economy can be allocated to the following classes: cash-flow constraints, collateral constraints, external funds limits, and financial regulations.

A prerequisite for the introduction of financial rigidity is failure of the ModiglianiMiller theorem on the independence of a firm's value from its funding structure. Modigliani and Merton (1958) formulated their theorem under the assumptions of efficient markets, the absence of distortions from tax system changes, zero bankruptcy costs, and perfect information. They have shown that for the total value of a firm it does not matter whether the funds of the firm are increased by shares or loans.

If the M-M theorem is at least approximately in line with reality, it is possible to omit the role of financial markets in obtaining funds because financial characteristics will become unimportant in the decision-making process. However, the omission of the role of financial markets has come under scrutiny since the theorem was formulated. An increasing number of studies incorporate financial factors into the models. The aim of these studies is to identify the mechanism for the transformation of observed shocks into fluctuations with properties corresponding to the observed properties of business cycles.

Mechanisms capable of transforming sudden and short-lived failures of financial markets into sharp and prolonged fluctuations in the real economy are generally labeled financial accelerator mechanisms. Bernanke, Gertler, and Gilchrist (1999) attributed the presence of a financial accelerator mechanism to the existence of an external finance premium (the credit channel, limiting the supply of external resources) or collateralization of debt (the collateral constraint channel).

\section{Credit Channel}

The external finance premium is a key concept of financial accelerator models, whose history begins with the studies of Bernanke and Gertler (1989) and Bernanke (1993) and continues with the papers by Bernanke and Gertler (1995) and Fukanaga (2002). This section focuses on models where external capital is used for

productive purposes. A focus on the use of debt due to its tax advantages for firm 
value optimization, as in Jermann and Quadrini (2009), is beyond the scope of this review.

In a frictionless world, a firm or entrepreneur is able to raise capital from external sources in exchange for a share in its future stream of profits. In the real world agents face certain restrictions when searching for external sources of capital. Restrictions occur due the limited supply of credit (credit rationing) or unattractiveness of the lending conditions. These restrictions originate from information asymmetry between the borrower and the lender. The cost of external financial resources is therefore a premium which a debtor must pay to creditors, generally in the form of higher interest. The premium can vary considerably and depends on many characteristics, such as company risk and net worth.

The external finance premium is defined as the difference between the cost to the borrower of raising capital in the financial markets (external funding) and the opportunity cost of the borrower's use of internal resources. De Graeve (2008) and Abhijit (2002) show that external funding (equity borrowed from creditors) is almost always more expensive than using internal resources (capital raised from own profits). This is due to the increase in the costs of lenders, who have to evaluate the prospects of success of the investment projects and monitor the borrower's conduct. For a better fit of the data, models should try to account for the observed positive premium on external funds.

Due to the costs of processes associated with obtaining external funding, the observed external finance premium is almost always positive. A debtor is financially assessed in terms of his net worth and the actual amount of liquidity and the expected income stream of his investment projects. The premium decreases with increasing net worth or liquidity and a proven record of realization of successful investment projects. A debtor with a better financial position and history is therefore rewarded by a lower cost of external sources of capital.

A fundamental property of the external finance premium is its countercyclical nature (Besley, Meads, and Surico, 2008) because the firm's income and worth increase in periods of economic growth. In the event of an adverse shock, the external finance premium increases, and that, in turn, increases the cost of obtaining external funding and worsens the financial position of the debtor. The further deterioration in financial position leads to an increase in the premium and a further reduction in demand for funding. The decrease in the utilization of resources leads to a reduction of investment projects and thus reduces economic output and the future stream of profits from projects. The profit decline leads to an increase in dependence on external funding and a decrease in net worth, leading to an increase in the premium. Therefore a small shock can significantly affect the whole economy for a long time via the financial accelerator mechanism.

Lenders face information asymmetry because they have less information about the status of investment projects than debtors do. Therefore, financial contracts include the possibility of costly monitoring of the status of the investment project. Monitoring of project results, as assumed by Diamond (1965), is linked with a significant cost of obtaining information, which increases the implementation costs. Akerlof (1970) presents a case in which the presence of information asymmetry may result in restriction of the functioning of the market or, in extreme cases (when 
contracts with full guarantees are used), in the establishment of barriers to the existence of a market. He also discusses measures that can eliminate or suppress information asymmetry to improve the functioning of markets.

Despite the costs, lenders use monitoring because without it the producers of capital would report lower than actual income. Moral hazard occurs because producers are trying to pay the lowest possible return, as Freixas and Rochet (2008) show. Townsend (1979) specifies a contract type able to handle information asymmetry and describes the properties of this contract. The optimal contract is defined by a function describing contract returns when bankruptcy or success occurs, as well as a monitoring threshold. The optimal contract is specified as follows: after the reporting of a project return higher than or equal to the threshold, the lender does not require auditing of the project result; if the reported profit from the project is lower than the monitoring threshold, the lender always requires an audit of the project result.

The threshold is a decreasing function of the amount of the borrower's capital, because a wealthier borrower can pay an agreed yield despite greater losses in the event of an adverse project result. The threshold is an increasing function of the risk-free return, which serves as an alternative to investing in the project. The difference between the monitoring threshold and the risk-free yield serves as an impulse for the emergence of financial agents who mediate the investment contract.

\subsection{Model by Bernanke and Gertler (1989)}

Bernanke and Gertler (1989) introduced entrepreneurs (producers of capital) and lenders into a model of overlapping generations, as this allows one to abstract from reputation and history of capital investment. A household in this model consists of entrepreneurs and lenders. Entrepreneurs use financial contracts to transform their assets and borrowed funds through investment projects into capital goods. The capital goods are used by firms to produce consumer goods. In the model by Bernanke and Gertler (1989), only entrepreneurs can see the results of their individual projects. Lenders have to pay monitoring costs to verify the results of investment projects.

The role of households is to take decisions on the quantities of goods consumed and saved. Saved goods are provided at a risk-free rate to a financial agent (a lender) and used by entrepreneurs (financial agents) to implement investment projects. Figure 1 shows the flow of goods and capital in this model.

Bernanke and Gertler (1989) consider financial agents who undertake business projects that produce capital demanded by firms producing goods. Financial agents try to meet the demand for capital by implementing investment projects and provide households with contracts with the possibility of auditing project results.

Monitoring costs combined with uncertainty about the project outcome create a positive premium on external resources. The existence of the premium and its procyclical nature are fundamentals of the financial accelerator mechanism, which propagates shocks to all parts of the economy.

To analyze the dynamics of the model, a positive shock to the productivity of firms is assessed. Expected growth in the price of capital leads to an increase in the expected profits of financial agents. Therefore, they increase their demand for 
Figure 1 Sketch of Agency Costs Model by Bernanke and Gertler (1989)

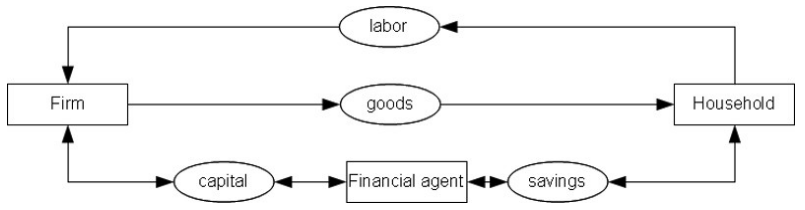

the goods used to produce capital and offer an increase in investment projects' profits. The growing profits of entrepreneurs increase their wealth, resulting in a downward shift of the monitoring threshold. As a consequence of the positive shock to productivity and the increase in net worth it is cheaper to acquire households' savings for the implementation of investment projects. This stimulates further growth of investment and capital production, which promotes future economic growth. Bernanke and Gertler (1989) called this type of amplification a shock accelerator effect on investment income. Subsequent studies recognize this mechanism as a financial accelerator.

\subsection{Model by Bernanke, Gertler, and Gilchrist (1999)}

One of the first attempts to introduce frictions, as presented by Townsend (1979), into the standard infinite horizon framework was the seminal paper by Carlstrom and Fuerst (1997). They embedded the contracting problem into the standard real business cycle model. Later on, Bernanke, Gertler, and Gilchrist (1999) presented an advanced model (the "BGG (1999) model") with a financial accelerator mechanism. The BGG (1999) model is a New-Keynesian DSGE model where financial intermediaries (producers of capital) face random termination (a mechanism capturing the ongoing births and deaths of firms). The termination allows them to abstract from investment reputation. Also, this prevents financial intermediaries from accumulating enough internal funds to achieve independence from external sources of funds.

In the BGG (1999) model, the economy is populated by households, firms, and retailers. Households supply labor, consume goods, and provide savings as shown in Figure 2. In addition, the government conducts both fiscal and monetary policy. The model is closed by a description of monetary policy, whose only role is targeting inflation.

The production sector is made up of heterogeneous firms set in a perfect competition environment which use capital and labor to produce consumption goods. The net worth of companies originates from investing their capital and labor and is assessed when obtaining the necessary capital to produce consumption goods via a financial intermediary. As in Carlstrom and Fuerst (1997), in the BGG (1999) model only one-period contracts between borrowers and lenders are feasible, as the introduction of longer-term contracts does not affect the basic results. The form of the financial contract and the assumption of production with constant returns to scale generates a linear relationship between demand for capital and entrepreneurial net worth and minimizes the expected costs of financial intermediation. Firms disappear and arise constantly. This prevents firms from accumulating enough resources to become independent of external sources of capital. The role of retailers is to buy consumption goods from firms and differentiate them costlessly. Households 
Figure 2 Sketch of BGG (1999) Model

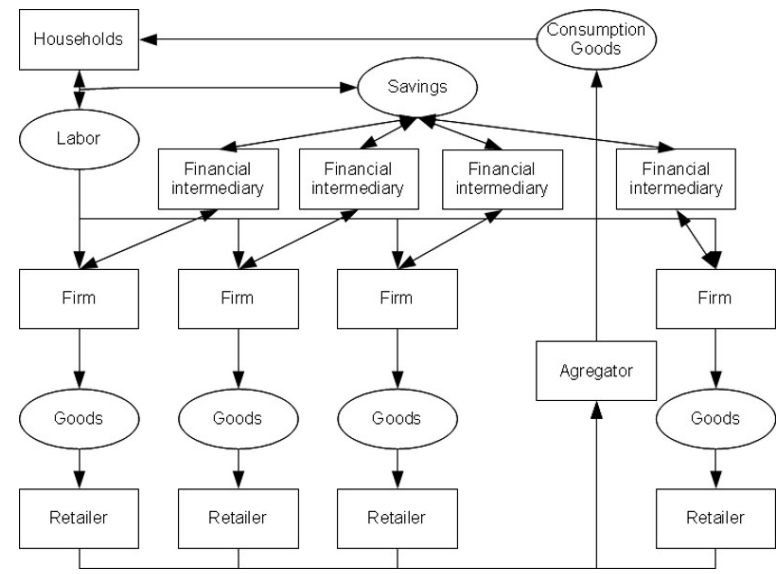

purchase aggregates of these goods. Price rigidity is introduced by the retailers offering differentiated products in an environment of monopolistic competition.

In the BGG (1999) model, the financial contract provides a monotonically increasing linear relationship between the capital-to-wealth ratio (leverage ratio, debt to assets, or debt to net worth) and the premium on external funds.

As the net worth of producers is pro-cyclical, a counter-cyclical external finance premium occurs. The counter-cyclical external finance premium imposes limits on the provision of funding for investment projects. The emergence of positive shocks reduces demand for external funding because an increase in profits from investment projects increases the net worth of producers of capital. However, as Joao, Amir, and Lu (2003) show, the empirical success of the costly external finance model lies partly in the fact that, for a fixed amount of internal funds, more investment requires more borrowing. This raises the monitoring costs and, consequently, the cost of external funds. This positive relation between investment and borrowing costs generates an increase in marginal adjustment costs and slows down capital accumulation in the early stages of an expansion, thus making it possible to obtain hump-shaped responses to underlying shocks. However, while this rise in marginal costs helps to generate large volatility in stock returns, it is necessarily associated with a pro-cyclical rise in the default premium, a feature that is at odds with the data. Thus, the same mechanism behind the realistic movements in key aggregates is also responsible for the model's shortcoming along the asset-pricing dimension.

Bernanke, Gertler, and Gilchrist (1999) expand their analysis of business cycles by comparing models with and without a financial accelerator mechanism.

As the impulse responses show, the financial accelerator mechanism itself does not deliver the desired properties of the responses. The authors contrast the immediate response to the monetary policy shock in the model with the usually delayed response in the data. They show that adding a delay in the investment process corrects this deficiency. The authors note that the presence of a financial accelerator may explain the extent and persistence of fluctuations, which are a response to monetary policy and demand and supply shocks. 
Figure 3 Flow of Funds and Services in Model by Aoki, Proudman, and Vlieghe (2004)

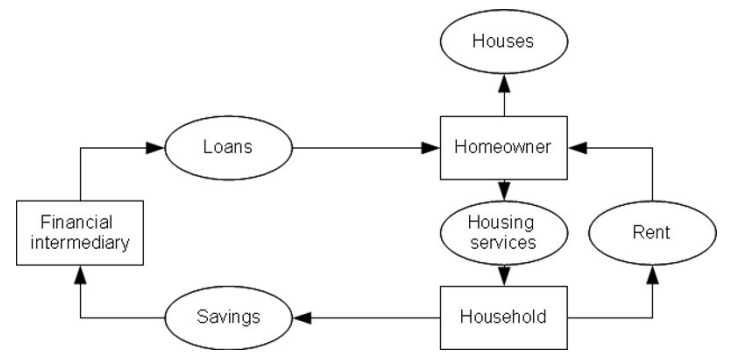

\subsection{Further Extensions of Models}

An early extension of the BGG (1999) model is presented by Christiano et al. (2003) in their analysis of the Great Depression. To capture the key forces of economic cycles, features such as perceptions of risk, disturbances to labor demand and capacity utilization, and wage frictions are introduced. Also, the model incorporates a banking system which is rich enough to consider the interactions between real economic activity and various monetary aggregates such as currency, bank reserves, and demand deposits.

The extended model identifies an increase in preferences for holding money and a shift away from savings over the analyzed period.

The model of Aoki, Proudman, and Vlieghe (2004) extends the BGG (1999) model to include investment in housing. Producers of capital are replaced by homeowners, who undertake investment projects that result in the provision of residential services to households, as Figure 3 shows.

Homeowners face an external finance premium when searching for capital for their real estate purchases. The motivation is based on the strong pro-cyclical nature of residential investment and house prices because investment costs depend on the structure of household wealth. Also, the demand for houses depends on the return from housing services and the expected marginal cost of financing. The model of Aoki, Proudman and Vlieghe (2004) is able to replicate the characteristics of the data (housing investment, housing prices, and consumption) and highlights the importance of the presence of an external finance premium to account for these properties.

The implications of including an external finance premium in the DSGE framework in order to match the data characteristics are generally based on the comparison of different models. Meier and Müller (2006) compare the model with a financial accelerator and the model with increasing capital adjustment costs. They focus on the monetary policy transmission mechanism, and so they primarily examine the responses to a monetary policy shock. They argue that both models are able to replicate the characteristics of the observed data on investment. As a result, the authors do not consider the external financing mechanism to be more important than the mechanism of costly investment for description of the properties of the transmission mechanism.

As most financial contracts are specified in nominal terms, Christiano et al. (2010) developed a financial accelerator model that allows producers to raise capital through nominal contracts. By comparing the model with and without the financial 
accelerator mechanism they identified only very small differences resulting from the inclusion of the external financing premium. Authors also identified only minor differences in the extent of fluctuations in real output and investment. Due to the use of nominal contracts, the authors attribute only minor importance to the financial accelerator mechanism in explaining the observed fluctuations in economic cycles as compared to the aforementioned studies.

Christensen and Dib (2008) extend the BGG (1999) model with two important features. First, the debt contracts in the extended model are written in terms of the nominal interest rate, reflecting the nature of debt contracts in developed economies. This adds the possibility of debt-deflation effects as mentioned in the literature on the Great Depression. Second, monetary policy is characterized by a modified Taylor-type rule under which the monetary authority adjusts short-term nominal interest rates in response to inflation, output, and money-growth changes. This is important because the response of monetary policy is an important element determining the quantitative importance of the financial accelerator. As Bernanke, Gertler, and Gilchrist (1999) note, the greater the extent to which monetary policy is able to stabilize output, the smaller is the role of the financial accelerator in amplifying and propagating business cycles in output or investment.

Christensen and Dib (2008) conclude that the inclusion of the financial accelerator mechanism leads to a better fit of the observed data properties. They show that their model has a better fit than the model without an accelerator and that the inclusion of the external financing premium allows the propagation of investment shocks to the rest of the economy with a gain in the amplification of fluctuations. Further, they focus on changes in the impulse responses to demand shocks, which show that introducing the financial accelerator greatly amplifies and propagates the effects of demand shocks on investment, while dampening those of supply shocks. Increased demand for consumption renders as a reduction in savings and increases the premium on external financing of capital formation. This increase in premium restricts the availability of capital required for the production of consumer goods for households, as it limits the response of producers to absorb the increased demand. However, the presence of the accelerator mechanism only marginally increases the volatility of output and other real variables. This is partly due to the aggressive response of the monetary authority to output variations produced by the estimated policy rule when the financial accelerator is included. However, as the variance decomposition shows, the inclusion of the accelerator extends the horizon of the monetary policy role for output fluctuations.

Generally, it can be concluded that the introduction of an external finance premium improves the fit of the economic data characteristics, such as the degree and persistence of fluctuations. However, the comparison shows that the effect of the external financing premium is strongly dependent on the assumptions.

External finance premium models are not able to generate the asymmetric character of the observed fluctuations. They neglect the direct effect of expectations of future economic development at the current premium level because the premium is derived only from the current value of the net worth of capital producers. Due to this fact, models with a financial accelerator mechanism have only a limited ability to capture the increase in bankruptcy rates seen during economic bad times. 


\section{Collateral Constraint}

An alternative approach to the external finance premium accelerator mechanism is to incorporate a limit on the amount of funds available. The limitation arising from the balance sheet is motivated by the creditworthiness of the borrower. The availability and amount of the debtor's assets facilitates the provision of loans by means of the debtor's assets (collateral) used to secure the loans.

When using a collateral constraint, in the event of bankruptcy of an investment project creditors may recover the debt only if the loans are fully secured. Loans are secured by the debtor's durable assets such as land, property, and long-term capital. These assets are transferred to the lender in the event of bankruptcy of the investment project. The nominal value of these durable assets determines the amount of the loan the borrower can get.

The emergence of asymmetry originates from comparison of the firm's decisions in cases with and without access to external resources. A general assumption of this comparison is that the allocation of financial capital and production facilities is optimal. In the case of sub-optimal allocation, the financial capital will be used to purchase production facilities to optimize the allocation. Assume that the firm is not able to obtain external resources and that it unexpectedly receives a temporary upward shock to income. Due to the assumption of optimal allocation of production factors, the firm either consumes this additional revenue or increases its financial capital.

When receiving an adverse shock, the response depends on the size of the shock. A small negative shock can be absorbed either by reducing the amount of financial capital or by reducing the consumption of resources. In the case of a large negative shock, it may happen that the financial capital is depleted. The firm then has to adjust the scope of its activities by reducing the number of production facilities.

However, under the assumption of the possibility of obtaining external resources, after the firm has depleted its own resources it will prefer to search for external resources and the return to the original optimal allocation of resources will be gradual and long lasting. Because the firm is able to absorb small positive and negative shocks, while large negative shocks have real effects on the extent of its production, the limit on the availability of funding acts as an asymmetric propagator of shocks.

The models of debt securitization are based on original work by Hart and Moore (1994). They describe a model of a financial contract for raising external capital funds under the assumptions that the debtor cannot guarantee success and may not be able to fulfill the terms of the project. The possibility of repudiation of the contract or bankruptcy of the project leads to the existence of an upper limit on debt (credit limit) that depends on the value of the assets which the debtor can use to secure his loan.

\subsection{Model by Kiyotaki and Moore (1997)}

Kiyotaki and Moore (1997) constructed a theoretical model in which firms use contracts with fully secured debt to obtain capital resources. They show how smallscale and temporary shocks to the productivity of firms can lead to significant fluctuations that spread throughout the economy. The assets of firms are used not 
Figure 4 Shock Acceleration in Model by Kiyotaki and Moore (1997)

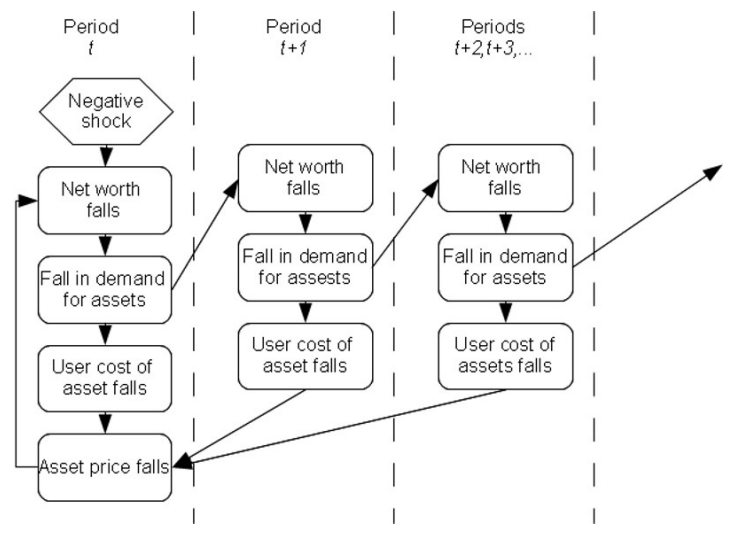

only for the production of consumer goods, but also as collateral. The source of the financial accelerator effect and propagation of technology shocks to the rest of the economy is the interaction of asset prices for debt securitization and credit limits.

In their model, households - farmers and gatherers - are characterized by different degrees of patience for consumption. Impatient farmers have a lower subjective discount factor that in equilibrium generates an incentive to borrow. Hence, the exante heterogeneity induces credit flows between the impatient farmers and the patient gatherers. Also, firms differ by the presence of credit limits arising from the presence of debt collateralization. Firms own capital (land) that can be used either for production of goods or as collateral when searching for external funds. The rest of the model is a standard model of real business cycles. Kiyotaki and Moore (1997) demonstrate that even small and short-term shocks to productivity or income distribution can cause prolonged changes in production, consumption, and prices of capital.

Figure 4 shows that a key mechanism in the acceleration of shocks in the model with debt collateralization is change in collateral value and its reflection in credit limits. A negative shock to the price of land leads to a decrease in the net worth of firms. Producers that become constrained by the credit limit are forced to reduce their demand for investment, including investment in land. The decline in demand for investment leads to a decrease in expected future output and income and a reduction in expected demand. The expected decline in demand for land by creditconstrained firms and the clearing of markets (to maintain equilibrium in the markets) forces credit-unconstrained firms to demand more land. This leads to a decrease in the opportunity cost of holding land, which amplifies the fall in the price of land in the initial period. Due to the expected and actual decline in the land price, the shock hurts the credit-constrained firms and forces deeper cuts in their investment in land.

Kocherlakota (2000) presents the motivation for including an asymmetric financial accelerator mechanism. He assumes that the land is owned by firms and serves as an alternative production factor to other means of production (e.g. machinery). The land can also be used as collateral for obtaining external funds. In the case of a large negative shock to demand, firms are forced to reduce the size of 
Figure 5 Model with Collateral Constraints by lacoviello and Neri (2010)

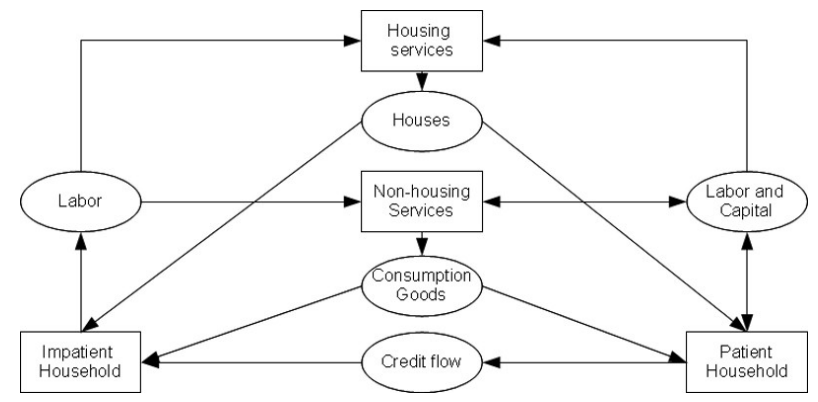

their manufacturing facilities. This leads to a reduction in the price of land because land and manufacturing facilities are alternative assets. This reduction in operation size lowers the limit on the amount of external resources that a firm can obtain via collateralized loans. This mechanism exaggerates the spread and amplification of the response to a negative shock to demand for the company's products.

Kocherlakota (2000) uses his theoretical models with secured debt to demonstrate that the mechanism of securing debt alone is not capable of delivering a strong financial accelerator effect. He shows that the strength of the financial accelerator mechanism increases with an increasing share in the production function of factors whose alternative function is debt securitization.

Cordoba and Ripoll (2004) consider the assumptions made by Kiyotaki and Moore (1997) as being too specific and conclude that the financial accelerator occurs due to constant returns to scale in the production of investment projects and to the willingness of lenders to support a project of any size. Under these assumptions, the amplification of fluctuations in real economic cycles can be generated by a small degree of smoothing and high utilization of assets to secure debt in the production function. Therefore, Cordoba and Ripoll (2004) opt to use more realistic assumptions. They demonstrate the insignificance of the financial accelerator effect for the amplification of responses. As their simulations indicate, large amplification can be obtained only with the combination of a low elasticity of intertemporal substitution, a large, but not too-close-to-one capital share, and a sizeable, but not too-close-to-one share of constrained agents. They conclude that unless one has this right combination of parameters, collateral constraints can generate amplification when compared with perfect-market models, but this amplification is small.

Like Christiano et al. (2010), Iacoviello (2005) is motivated by the criticism of real contracts to construct a model with nominal contracts and demand for real estate. The holding of real estate provides the benefit of housing to households and secures debt. Iacoviello (2005) is able to show an asymmetric response to shocks, as after a period of positive shocks and under the assumption of nominal contracts, the credit limit does not constrain the size of the loan. This supports the importance of collateralized debt for the presence of a financial accelerator effect.

Iacoviello and Neri (2010) constructed a model to reflect the characteristics of fluctuations in household consumption with two sectors of production, as Figure 5 illustrates. The housing sector utilizes capital, land, and labor to provide housing 
services. Consumption goods and business capital are produced in the non-housing sector by utilization of labor and capital.

As an extension to Kiyotaki and Moore (1997), Iacoviello and Neri (2010) consider two types of households: patient and impatient. Patient households work, consume, accumulate housing, supply capital to firms, and supply funds to impatient households. Impatient households work, consume, and accumulate housing; they only accumulate the net worth required to finance the down payment on their home. Due to an inability to fully enforce repayments of debt, impatient agents have to use the housing stock as collateral. Also, the housing stock provides utility, in addition to consumption and leisure.

The results support the importance of the mechanism of collateralized debt, as it amplifies the financial accelerator effect and propagates shocks from the housing market to the rest of the economy. Negative price shocks in the housing market, via the collateral constraint, reduce the amount of household loans used to facilitate household consumption.

The relationship between house prices and household consumption allows the model to capture the extent of fluctuations in the growth of household consumption as observed in the data. The finding of earlier studies that the impact of credit constraints is muted motivates Liu, Wang and Zha (2010) to re-examine the comovement of housing and investment and they show that the credit transmission mechanism introduced by Kiyotaki and Moore (1997) is empirically relevant. In the model by Liu, Wang, and Zha (2010), the household consumes a homogeneous good, housing services, and leisure, and supplies labor and loanable funds in competitive markets. The entrepreneur consumes and produces the homogeneous good. Production of the good requires labor, capital, and land as inputs. To finance consumption, production, and investment, the entrepreneur borrows loanable funds subject to a credit constraint. Land and capital serve as both inputs for production and collateral for borrowing.

Liu, Wang, and Zha (2010) conclude that the previously found muted impacts of credit constraints are due to the focus on total factor productivity (TFP) shocks. A TFP shock does not have a large impact on asset prices because it moves future dividends and the risk-free interest rate in the same direction. Previous studies fail to obtain positive comovements between housing prices and business investment because they assume that a subset of households, instead of entrepreneurs, are creditconstrained. Allowing entrepreneurs to be credit-constrained is an essential feature of Liu, Wang, and Zha's (2010) model for generating persistent comovements between the housing price and business investment. As the housing demand shock raises the land price, it also raises the entrepreneur's net worth and borrowing capacity, which provides an incentive for and enhances the ability of the entrepreneur to increase business investment. Through the dynamic interactions between the land price and investment, a shock to housing demand is amplified and propagated to generate important macroeconomic fluctuations.

The models of collateralized debt can be extended to an open economy framework. The introduction of an external finance premium into the small open economy model can be used to describe the spread of financial distress among open economies (e.g. Brzoza-Brzezina and Makarski, 2009). 
As in the case of the external finance premium, the quantitative significance of introducing a financial accelerator by means of collateralized debt is not straightforward. The amplification of the responses and the increase in their persistence depends on the parametrization and assumptions of the models used. In collateralized debt models, the use of nominal contracts attenuates the effects of the financial accelerator mechanism in the case of supply shocks. As in the external finance premium models, reinforcement of the accelerator mechanism can be achieved by increasing the share of collateral in the production function.

The extent of the financial accelerator mechanism's effects also depends on the origin of the shock that drives the fluctuations. It is possible to observe significant amplification of the responses to financial shocks, as these shocks affect the prices of the goods used to secure loans (such as real estate and durable goods). By contrast, usually only a weak financial accelerator effect can be observed for non-financial shocks, which can only slightly affect the amount of the credit limit and demand for collateral.

\section{Banking Sector}

The presented models of financial frictions were constructed without an explicit role for banks. The focus was primarily on the demand side of credit. The role of banks and other financial institutions was not specified, as financial contracts are arranged directly in the financial market under the known form of a contract for the acquisition of external funding. The literature introducing a banking sector into DSGE models has been motivated mainly by the aim of explaining specific features of the financial crisis. The research on models with a banking sector examines questions related to the role of banks in the financial market. The goal is to explain banks' behavior.

The seminal models introducing a banking sector into the DSGE framework have focused on highlighting the necessity for monetary policy to account for differences between the interbank interest rate and other short rates, e.g. the government bond rate. The following research extends the framework by adding various financial frictions and agents in order to study the role of bank capital in business cycle fluctuations. The financial crisis has emphasized the importance of systemic risk and sudden changes in that risk. Thus, the studies below search for the foundations for the existence of risky portfolios. The liquidity crisis after the Lehman collapse triggered the development of models studying the function of the bank capital requirement in the process of loan creation. Last but not least, monetary policy actions have motivated studies of the Fed's unconventional policy instruments during the financial crisis.

The pioneering model introducing banks into the DSGE model is by Goodfriend and McCallum (2007). The model builds on the methodology of Bernanke, Gertler, and Gilchrist (1999). A banking sector is introduced to describe the interaction and differences between various types of interest rates to determine how much the central bank is misled by relying on a standard model without a banking sector. The credit and balance sheet channels are placed in the banking sector. The banking sector is set up similarly as a firm's optimization problem. Loan creation in the competitive banking firm sector is introduced by the production function and cash-inadvance assumption. 
Loan production depends on collateral and loan-monitoring costs. The authors use a standard Cobb-Douglas production function with two inputs: collateral and labor. Both government bonds and capital can be used as collateral. However, capital is inferior to bonds as collateral because the related monitoring costs of the true value of capital are higher than those for government bonds. Labor input is used to monitor loans. The importance of the cash-in-advance assumption lies in its attribute of relating consumption to deposits and introducing the medium-of-exchange property of money. To pay for consumption spending, the household has to hold a given amount of deposits at the time of purchase. Therefore, the cash-in-advance assumption creates demand for deposits in the model.

The competitive banking market setup creates two opposite external finance premium effects. The first is called the "banking attenuator" effect. The banking sector attenuates a monetary policy shock because the external finance premium grows in booms and drops in recessions. The intuition for this lies in the formulation of the banking sector production function and in the cash-in-advance constraint faced by the household when purchasing consumption goods. This constraint forces the household to hold cash for goods purchases in advance and constitutes a need to hold deposits before buying consumption goods. An expansionary monetary shock drives consumption growth in the model economy. The higher consumption generates a proportional increase in the demand for bank deposits. Growing loans require more banking services to monitor the collateral value. Consequently, the concave character of the Cobb-Douglas production function implies that the monitoring costs grow faster than the amount of loans. The higher costs of lending given by the increased spread between the loan rate and the reference rate discourage demand for loans and further dampen consumption growth.

On the other hand, the "banking accelerator" effect arises from the fact that the monetary policy shock raises the opportunity cost of investment, therefore the marginal product of capital and the price of capital have to increase. The higher price of capital increases the collateral value and hence implicitly decreases the monitoring costs. The increased demand for deposits is compensated by a lower marginal cost of loan production. Goodfriend and McCallum (2007) argue that for reasonable parameter values the "attenuator" effect is stronger and the external finance premium is procyclical.

The next important contribution to the literature comes from Cúrdia and Woodford (2009). The important novelty to Goodfriend and McCallum is given by the specific model framework. Cúrdia and Woodford (2009) develop a stylized model with a banking sector where the basic New-Keynesian model is its special case. They differ in their modeling approach by assuming heterogeneous households able to change their type. This implies that the credit spread is a function of the markup in the intermediary sector and the costs of the loan. The modified model delivers an economy with financial intermediation realized between households rather than households and firms. Half of households are lenders and the other half borrowers. Borrowers have a higher marginal utility of consumption than lenders. As savers discount the future less than borrowers, the optimality conditions of the model contain two discount factors. Consequently, the model produces two different interest rates. The spread between the interest rate available to savers and the interest rate that borrowers pay for the loan is time varying. 
In order to keep the model tractable, Cúrdia and Woodford (2009) come up with an elegant solution and introduce insurance against both the aggregate risk and the idiosyncratic risk associated with a change of household type. Without insurance, the distribution of the marginal utility of income would be too dispersed because of the histories of each individual type of household and the model would not have a stable solution. The fact that the change of household type is random, together with the insurance, enables the authors to perform aggregation and derive a stationary equilibrium. The heterogeneous agent approach allows the authors to abstract from the assumption that households need to hold deposits before purchasing goods.

The paper's main implication for monetary policy is that including the credit channel in the standard New-Keynesian (NK) model does not fundamentally alter optimal monetary policy. The response to a financial shock should be the same as that to the linear combination of shocks standard in New-Keynesian models. An interesting exception is the fiscal shock. In the basic NK model, Ricardian equivalence holds, while in the model with credit frictions changes in the path of government debt have significant effects on inflation, output, and interest rates. These effects arise from the assumption that government borrowing is not subject to credit frictions. Thus, even if government borrowing crowds out private borrowing one to one, the absence of credit frictions (production of public debt is cheaper) leads to higher output and a lower loan rate. In other words, investors lending to the government do not require collateral and do not pay for monitoring. Consequently, the growing volume of lending does not increase the time-varying spread between the deposit rate and the lending rate.

The influence of the paper by Cúrdia and Woodford (2009) lies in the fact that they build on the broadly known baseline NK model and carefully discuss all its assumptions and its derivation. On the other hand, omitting frictions in financial intermediation may give rise to false policy implications of the model. The modeling of the spread abstracts from the threat of default, one of the main driving forces determining the interest rate spread. Christiano, Trabandt, and Walentin (2007) ask if the banking sector, and the financial sector in general, are quantitatively important for the business cycle and what the possible implications are for monetary policy. They extend the model of Bernanke, Gertler, and Gilchrist (1999) by introducing a financial sector and estimate it by Bayesian methods. The modeling approach to banking is in the spirit of Goodfriend and McCallum (2007) in the way liquidity is supplied. Instead of a loan production function, however, they use a deposit production function. They argue that the BGG (1999) type of financial frictions improves the data fit, but the banking sector plays a small role. The function of monetary policy in accommodating financial shocks is limited in their model.

To reflect issues associated with credit risk, further research using a banking sector in DSGE models integrates endogenous banking capital into the bank's balance sheet. Gerali et al. (2009) introduce a banking sector into the DSGE model to study the role of banking intermediation, in particular the implication of tightening credit conditions and their transmission to the real economy. They merge the model of Christiano, Trabandt, and Walentin (2007) and Iacoviello (2005) and extend it to include an imperfectly competitive banking sector in both the deposit market and the loan market. This setup has important consequences for monetary policy because the central bank policy rate is not transmitted fully and instantaneously into 
households' and firms' decisions. The monopolistic power of banks over the loan and deposit rate changes the pass-through of the policy rate. Gerali et al. (2010) extend the model to estimation by Bayesian techniques and provide a more thorough discussion of the policy implications.

Explanation of the stylized facts of the global financial crisis motivates Christiano et al. (2010) to further extend their earlier model in a way that can explain the main elements of the crisis. They find that liquidity constraints and changing risk perceptions are the main determinants of economic fluctuations. Financial frictions in the credit supply turning market risk into systemic risk contribute importantly to the model's empirical fit. The ability of the central bank to supply liquidity when the supply of credit in the banking sector is low has significant smoothing effects on the business cycle.

Another sub-class of models with a banking sector concentrates on analysis of the Fed's unconventional balance sheet operations in reaction to the consequences of the financial crisis. Gertler and Karadi (2011) use a model with an agency problem between intermediaries and their depositors to produce endogenous constraints on intermediary leverage ratios, as a drop in banks' capital has an impact on borrowing and lending. A specific feature of the model is that the central bank acts as an intermediary. The monetary authority can borrow funds from savers and then lend them to investors. The distinction from private banks lies in the fact that the central bank does not face constraints on its leverage ratio. The central bank borrows against collateral in the form of government bonds. By buying its own debt the central bank avoids agency problems. Gertler and Karadi (2011) show that especially when the policy rate hits its zero lower bound the net benefits of unconventional monetary policy are significant. This model is extended in Gertler and Kiyotaki (2010) by the introduction of an interbank market. The paper models the situation where banks are not willing to lend to one another. Banks face an idiosyncratic liquidity shock which creates a deficit or surplus of funds across financial institutions. Together with agency problems, the disruption to the inter-bank market affects real activity. These models are used to illustrate the fact that various credit market interventions may mitigate the negative effects of financial frictions at times of crisis.

The most recent contributions to the literature dealing with the banking sector in DSGE models go back to the roots of the financial crisis and search for the underlying rationality in building risky portfolios. The contribution of Gertler, Kiyotaki, and Queralto (2011) focuses on explaining the motivations of banks to take excessive risks. Their aim in their very recent working paper is not just to match the banks' vulnerability to risk, but also to explain why banks tend to build risky balance sheets. The modeling framework builds on Gertler and Karadi (2011) and Gertler and Kiyotaki (2010). The endogenous choice of a risky balance sheet is incorporated by a trade-off between short-term debt and equity. The authors conclude that appropriately designed macroprudential policy can mitigate moral hazard costs. Incentives for risk taking reduce the benefits of credit policies stabilizing the financial markets.

A synthesis of much of what can be found in the previous models is provided in the model by Dib (2010). Dib (2010) unifies many of the ingredients of previous research and adds an analysis of a bank's capital requirement condition and its effects on business cycle fluctuations. 


\section{DSGE and Macroprudential Analysis in the CNB}

Though the financial crisis has led to an increase in interest in DSGE models featuring financial frictions and an endogenous financial sector, the models described in previous sections usually comprise purely academic research and their policymaking applications are relatively limited. This section summarizes some arguments discussed in connection with the practical use of such models both in monetary policy and in macroprudential policy.

\subsection{Use of Financial Frictions for Monetary Policy Purposes}

As summarized in the previous sections, and as discussed within the central banking community, the potential gains arising from including financial frictions in central banks' prediction models can be large. The extension of the models used by central banks to include financial frictions helps improve the fit of these models and our understanding of the historical development of economic indicators. Also, it can lead to improvements in the calibration of the relevant coefficients and elasticities. Extended models also strengthen prediction capability and thus improve the conduct of monetary policy. Capabilities are further improved by an understanding and quantification of the transmission mechanisms of monetary policy to the real economy.

Though many central banks have experimented with DSGE models with financial frictions there is no unified approach that represents the "state of the art," in contrast to the use of "traditional" DSGE models, where the models are to some extent standardized (see Tovar, 2009). As Brůha et al (2011) discuss, this is due to the following reasons:

- The review of approaches to financial frictions in previous sections shows that there are numerous approaches and variations thereof. These approaches differ in the nature of the financial frictions and also in their transmission to the real economy and can give rise to diverse quantitative results.

- At the same time the models have to be focused on specific individual types of frictions to keep them operational. It is virtually impossible to model several types of financial frictions at once, as this would make such models very complex.

- Interaction between different types of financial frictions could lead to very complex implications-interacting frictions could amplify or suppress each other.

- Acceptance or rejection of the significance of financial frictions is complicated by the fact that episodes of financial sector turmoil are quite rare. Also, the relevant data series are not available in sufficient length or quality.

Given the above-mentioned uncertainties relating to the selection of the relevant type of financial frictions for the prediction model, the CNB's policy is to keep its benchmark G3 model unchanged (for a description of the model properties see Andrle, Hledik, Kamenik, and Vlček, 2009) and develop a set of several parallel satellite models using different types of financial frictions. There are several streams of model development going on in the CNB research program, ranging from workstreams aspiring to incorporate the financial accelerator mechanism into a small open economy (with an alternative assumption of original "state contingent contracts" as 
well as an extension to "state non-contingent contracts" developed by Kumhof and Beneš, 2011), through workstreams aiming to include housing markets in DSGE models, to workstreams that set out to build DSGE models with a banking sector.

\subsection{Use of Models with Financial Frictions for Macroprudential Policy Purposes}

While the use of DSGE models with financial frictions for monetary policy is relatively straightforward (matching the properties of macroeconomic fluctuations and understanding the full scope of monetary policy transmission channels), their use for macroprudential policy is much more demanding. The practical applications of such models are quite rare and are focused mainly on stylized evaluation of the effects of macroprudential instruments on macroeconomic performance.

This results from the setup, as the objectives of macroprudential policy are broader than those of traditional monetary policy and thus are still not fully settled (for a discussion of macroprudential policy issues see Frait and Komárková, 2010). Furthermore, restrictions on the use of DSGE models originate from the fact that macroprudential analysis often orients itself toward assessment of the vulnerability of a financial system to exceptional but plausible events, which are often related to non-equilibrium, divergent states of the financial system. These states cannot easily be modeled by standard equilibrium models, which are dependent on an appropriate definition of the steady state.

However, DSGE models are often used in practice for creating scenarios for the most commonly used tool of macroprudential analysis: stress testing (for a review of the use of stress testing in central banks see, for example, Čihák, 2006). This is especially true for central banks that use DSGE models for standard monetary policy analysis, such as the Czech National Bank. ${ }^{1}$

The use of DSGE models in the creation of stress-testing scenarios has advantages due to the following features of this process. The stress-testing scenarios always include a "baseline scenario," which is supposed to be the most likely scenario of future macroeconomic development and which should be in line with the official central bank forecast. Also, compared to the various types of central bank prediction models, DSGE prediction models introduce far more degrees of freedom in the creation of stress scenarios. DSGE models usually include many sources of volatility (shocks), allowing alternative trajectories to be modeled. Finally, DSGE models usually rely on calibrated parameters, which can be altered to match the requirements of the stress scenario. This option can only be used in very specific cases.

This shows that stress scenarios based on DSGE models are much more flexible. However, the main advantage of using a DSGE model when creating stresstest scenarios is that it delivers model-consistent future paths of the relevant macroeconomic variables.

The current banking sector stress-testing framework is illustrated in Figure 6. The DSGE model generates the scenarios (part I of the diagram) used in the initial assessment of market risks (interest rate and foreign exchange risks; see part II of

\footnotetext{
${ }^{1}$ For a description of the CNB's DSGE model used for supporting monetary policy decisions, see Andrle, Hledik, Kamenik, and Vlček (2009). For a description of the three generations of the stress-testing models used in the CNB see Čihák and Heřmánek (2006), Čihák, Heřmánek, and Hlaváček (2007), and Geršl and Seidler (2010).
} 
Figure 6 Use of DSGE Models in Building Up Macroeconomic Scenarios for Stress Testing

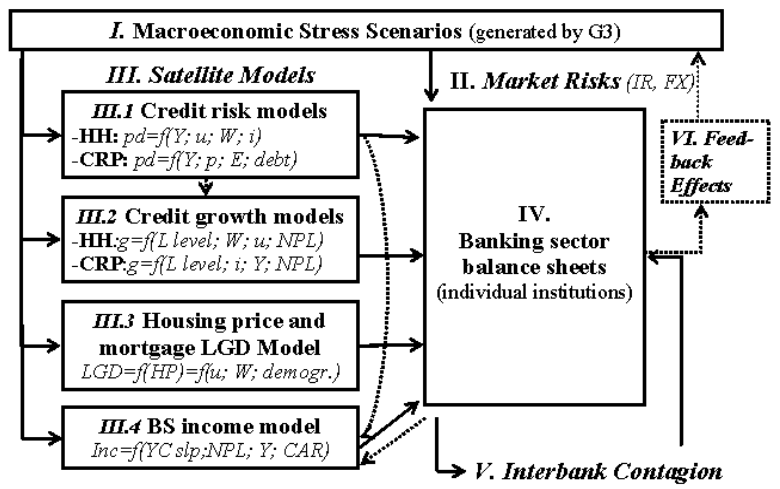

the diagram). These are directly reflected in banking sector balance sheets (part IV of the diagram), which form the main "body" of the stress testing. The macroeconomic variables from the stress scenarios then enter numerous satellite models (parts III.1-III.4). The outcomes of the satellite models again enter the banking sector balance sheets and generate additional stress on banks.

The aforementioned individual satellite models often use different methodologies that range from simple ad-hoc approaches to more sophisticated Merton-type models. In this framework it is also important for the individual satellite models to be interrelated, which causes other problems. ${ }^{2}$ In addition to the impacts of different types of risks on banking sector balance sheets, the current stress-testing framework includes models of interbank contagion, which try to capture the role of interconnectedness within the banking sector (part V of Figure 6; see Čihák, Heřmánek, and Hlaváček, 2007) and also some feedback effects influencing the real economy (part VI of the diagram; see Geršl and Jakubík, 2010). In contrast to the stress-testing framework, which is quite detailed, especially in its banking sector balance sheet segment, the feedback effects to the real economy are quite stylized and are not included in every stress-testing exercise.

The above discussion of the current use of DSGE scenarios in stress testing might also produce some guidelines on how extended versions of DSGE models featuring elements of the financial sector could help in creating more realistic stresstesting scenarios. Clearly the inclusion of the financial frictions described in sections 3 and 4 (i.e., in models without banking sector capital) would lead to a wider set of model/scenario-generated variables, which, in turn, could lead to better estimation of the satellite models. Moreover, in the second step the DSGE model extended to include financial frictions could widen the initial macroeconomic scenarios (part I of Figure 6) to encompass variables that are now being generated by the current satellite models (e.g. defaults, credit growth or housing price growth). Thus, such an "extended"

\footnotetext{
${ }^{2}$ This is depicted in Figure 6 by dotted arrows, e.g. the projected probability of default from the credit risk model influences the share of non-performing loans, which enters the banking sector income model with a lag. One could also think about interrelations between housing price growth and mortgage loan development and other mutual links.
} 
macroeconomic scenario could under some circumstances integrate some of the current satellite models. This approach could help to solve the above-mentioned problems with interrelation of the individual satellite models. Moreover, such an extended macroeconomic scenario could include some of the feedback effects between the real economy and financial variables that are not included in the current framework (e.g. the link between investment and loans to the private sector and others).

The "second generation" of DSGE models featuring a financial sector that already includes an explicit banking sector (section 5) could lead to a third step of integration of DSGE models into the stress-testing setup. In this case it could eventually replace the remaining satellite models (e.g. the banking sector income model III.4) and to some extent even the "core" of the stress testing, namely, the banking sector balance sheets (part IV of the diagram). This "cannibalization" of the stress testing would have the clear advantage of model-consistent modeling of feedback effects (part VI of Figure 6).

DSGE-based models could also help the current setup by prolonging its prediction horizon. ${ }^{3}$ Within "boom and bust" cycles, ${ }^{4}$ stress testing covers only the "cleaning" or "resolution" phase, when the risk has already materialized. However, its ability to model the gradual build-up of risks in the "leaning phase" is substantially limited by this short horizon.

As mentioned in previous sections, within these endogenous boom and bust cycles, DSGE models with a financial sector are able to fit the procyclicality of the financial system. This originates from their ability to capture the endogenous relation between the real economy and the financial sector and to better model the feedback effects.

However, the DSGE type of models will never replace stress testing, especially in its cross-sectional dimension. They are not able to include detailed information on the distribution of individual banks' characteristics, which is crucial in the assessment of the sustainability of the banking sector (including ad-hoc stress-testing exercises). Also, such models are not able to assess interbank contagion. Thus, traditional stress testing, though methodologically quite simple, will always have an advantage in terms of flexibility. Therefore, it is clear that DSGE models with a financial sector will complement rather than replace current stress-testing practice. It has to be mentioned that DSGE models with a financial sector have to be tailormade for each country.

\section{Conclusion}

In this survey, mechanisms for including financial intermediaries and financial rigidities into general equilibrium models are described. The inclusion of these mechanisms is motivated by the observed property that even a small financial shock

\footnotetext{
3 The stress test currently uses a 2-year horizon, but it is being prepared for extension to the 3-year horizon.

${ }^{4}$ Systemic or macro-prudential risk is supposed to have two dimensions (see Frait and Komárková (2011)). One is the time dimension, which reflects the build-up of systemic risk over time and relates to endogenous boom and bust cycles and procyclicality in the behavior of financial institutions. Macroprudential policies should be different in the leaning and cleaning phases-firstly the prevention of systemic risk, and then, if prevention fails, mitigation of the impacts when risks materialize. The second, cross-sectional, dimension of systemic risk reflects the interrelationships between individual financial institutions at a given point in time via both their mutual and chained exposures.
} 
can cause a significant and long-term response. General equilibrium models are useful for various monetary policy experiments and predictions of shock impacts. Standardized versions of these models, however, expect the financial markets to function smoothly and provide external sources of capital without price distortions and without limits.

Financial frictions can be included by introducing an external financing premium due to the risk of a debtor defaulting on a financial contract for the provision of external resources. The premium originates from costly monitoring of the debtor.

Financial frictions can also be included by imposing restrictions on the amount of external sources that the debtor may obtain. This restriction is based on the need to collateralize the loan to cover inability to fulfill obligations under a financial contract.

Both of these approaches for including financial frictions lead to the emergence of a financial accelerator mechanism, whose presence leads to the amplification of shocks. This amplification can explain the observed volatility of aggregate economic output. However, these approaches do not specify a role for financial intermediaries. This survey also contains a description of approaches to specifying this role in financial markets. However, it is often found that the inclusion of financial intermediaries mutes the extent of the financial accelerator. Despite the rapid expansion of the use of general equilibrium models, these models are not yet able to capture all relevant features of the data - the degree and persistence of fluctuations. However, an analysis by Tovar (2009) highlights the role of these models in the decisions of central banks. Describing the observed data properties is a challenge for these models and their users, who will face more complex models whose properties and responses are difficult to manage, analyze, and communicate.

The use of the financial frictions DSGE model in practical monetary policy is currently limited by the absence of a unified approach representing the "state of the art". The absence of a standardized approach originates from the large number of approaches to the implementation of financial frictions. Moreover, to deliver operational models with operational financial frictions, it is difficult to model several types of frictions at the same time. The estimation/calibration of such models is complicated by the low frequency of episodes of financial stress. Because of these uncertainties, the policy of the CNB is to develop several alternative satellite models which complement the core prediction model. The use of DSGE models with financial frictions in macroprudential policy is even less straightforward than their use in monetary policy. This is due to the broader setup and objectives of macroprudential policy, which are not settled yet. DSGE models with financial frictions can be used to create scenarios for existing macroprudential analysis tools and stress testing. The introduction of DSGE models with financial frictions may help to improve estimation of the satellite stress-testing models and eventually absorb some of the satellite models. DSGE models featuring an explicit role for the banking sector can help improve modeling of feedback effects between the real economy and financial variables. DSGE models can be helpful for extending the forecast horizon in the current forecasting framework. Within "boom and bust" cycles this could improve modeling of the gradual build-up of risks during the "leaning phase" of the financial cycle. 
Finally, DSGE models with financial frictions should deliver new insights into the time dimension of systemic risk and cast more light on financial sector procyclicality. However, the current state of DSGE modeling does not provide enough evidence that this type of model will be able to replace stress testing, especially in its cross-sectional dimension.

\section{REFERENCES}

Acemoglu D, Scott A (1997): Asymmetric Business Cycles: Theory and Time-series Evidence. Journal of Monetary Economics, 40(3):501-533.

Akerlof GA (1970): The Market for 'Lemons': Quality Uncertainty and the Market Mechanism. The Quarterly Journal of Economics, 84(3):488-500.

Andrle M, Hledik T, Kamenik O, Vlček J (2009): Implementing the New Structural Model of the Czech National Bank. Czech National Bank, Working Papers, no. 2009/2.

Angelini P, Neri S, Panetta F (2011): Monetary and Macroprudential Policies. Bank of Italy (Economic Research and International Relations Area), Temi di discussione (Economic Working Papers), no. 801.

Aoki KPJ (2004): House Prices, Consumption, and Monetary policy: A Financial Accelerator Approach. Journal of Financial Intermediation, 13(4):414-435.

Banerjee AV (2002): Contracting Constraints, Credit Markets and Economic Development. MIT Dept. of Economics Working Papers, no. 02-07.

Dewatripoint M, Hansen L, Turnovsky S (Editors): Advances in Economics and Econometrics: Theory and Applications, chapter 1 (pp. 1-46). Cambridge University Press.

Bank for International Settlements (2011): Research Task Force Working Group on the Transmission Channels between the Financial and Real Sectors of the Basel Committee on Banking Supervision. The Transmission Channels Between the Financial and Real sectors: A Critical Survey of the Literature. Working Paper, no. 18.

Bernanke BS (1993): Credit in the Macroeconomy. Quarterly Review, (Spring):50-70.

Bernanke BS, Gertler M (1989): Agency Costs, Net Worth, and Business Fluctuations. American Economic Review, 79(1):14-31.

Bernanke BS, Gertler M (1995): Inside the Black Box: The Credit Channel of Monetary Policy Transmission. The Journal of Economic Perspectives, 9(4):27-48.

Bernanke BS, Gertler M, Gilchrist S (1999): The Financial Accelerator in a Quantitative Business Cycle Framework. Handbook of Macroeconomics. In: Woodford M, Taylor JB (Eds): Handbook of Macroeconomics. Ed. 1, vol. 1, chapter 21 (pp. 1341-1393). Elsevier.

Besley TJ, Meads N, Surico P (2008): Household External Finance and Consumption. CEPR Discussion Papers, no. 6934.

Brůha J, Hlédik T, Polanský J, Ryšánek J, Tonner J, Vlček J (2011): Role finančních frikcí v MP rozhodování (The Role of Financial Frictions in Monetary Policy Decision Making). Internal CNB document.

Brzoza-Brzezina M, Kolasa M, Makarski K (2011): The Anatomy of Standard DSGE Models with Financial Frictions. National Bank of Poland Working Papers, no. 80.

Brzoza-Brzezina M, Makarski K (2009): Credit Crunch in a Small Open Economy. MPRA Paper, no. 18595 (University Library of Munich, Germany).

Carlstrom Ch, Fuerst T (1997): Agency Costs, Net Worth, and Business Fluctuations: A Computable General Equilibrium Analysis. American Economic Review, 87(5):893-910.

Cochrane JH (1994): Shocks. Carnegie-Rochester Conference Series on Public Policy, 41:295-364. 
Cordoba J, Ripoll M (2004): Credit Cycles Redux. International Economic Review, 45(4):10111046.

Cúrdia V, Woodford M (2009). Credit Frictions and Optimal Monetary Policy. BIS Working Papers, no. 278.

Čihák M (2006): How Do Central Banks Write on Financial Stability? IMF Working Papers, no. $06 / 163$.

Čihák M, Heřmánek J (2005): Stress Testing the Czech Banking System: Where Are We? Where Are We Going? Research and Policy Notes, 2005/02 (Czech National Bank, Research Department).

Čihák M, Heřmánek J, Hlaváček M (2007): New Approaches to Stress Testing the Czech Banking Sector. Finance a úvěr - Czech Journal of Economics and Finance, 57(1-2):41-59.

Darracq Paries M, Kok Sørensen Ch, Palenzuela DR (2010): Macroeconomic Propagation Under Different Regulatory Regimes: Evidence from an Estimated DSGE Model for the Euro Area. Working Paper Series, no. 1251, European Central Bank.

Derviz A, Seidler J (2010). Macroprudential Policies in Small Open Economies: Specifics, Effectiveness, Limits. CNB research project, B3/11, Czech National Bank.

Diamond PA (1965): National Debt in a Neoclassical Growth Model. The American Economic Review, 55(5):1126-1150.

Dib A (2010): Banks, Credit Market Frictions, and Business Cycles. Bank of Canada, Working Papers, no.10-24.

Falk B (1986): Further Evidence on the Asymmetric Behavior of Economic Time Series over the Business Cycle. The Journal of Political Economy, 94(5):1096-1109.

Frait J, Komárková Z (2011): Financial Stability, Systemic Risk and Macroprudential Policy. CNB Financial Stability Report 2010/2011 (Czech National Bank, Research Department).

Franta M, Beneš J, Hlaváček M (2009): Developing the Czech National Bank's Integrated Monetary and Macro-Prudential Policy Framework. CNB research project, B1/11, Czech National Bank.

Freixas X, Rochet J (2008): Microeconomics of Banking. The MIT Press, 2nd edition.

Fukunaga I (2002): Financial Accelerator Effects and Japan's Business Cycle. Working Paper, no. 6, Bank of Japan.

Gelain P (2011): Macro-Prudential Policies in a DSGE Model with Financial Frictions. In: $7^{\text {th }}$ Dynare Conference, Atlanta, USA.

Gerali A, Neri S, Sessa L, Signoretti FM (2009): Credit and Banking in a DSGE Model. In: Laxton D, Leon L (Eds): Macro-Linkages, Oil Prices and Deflation Workshop. IMF.

Gerali A, Neri S, Sessa L, Signoretti FM (2010): Credit and Banking in a DSGE model of the Euro Area. Temi di discussione (Economic Working Papers), no. 740, Bank of Italy.

Geršl A, Jakubík P (2010): Procyclicality of the Financial System and Simulation of the Feedback Effect. CNB Financial Stability Report 2009/2010, Czech National Bank, Research Department.

Geršl A, Seidler J (2010): Stress Test Verification as Part of an Advanced Stress-Testing Framework. CNB Financial Stability Report 2009/2010, Czech National Bank, Research Department.

Gertler M (1988): Financial Structure and Aggregate Economic Activity: An Overview. Journal of Money, Credit and Banking, 20(3):559-88.

Gertler M, Karadi P (2011): A Model of Unconventional Monetary Policy. Journal of Monetary Economics, 58(1):17-34.

Gertler M, Kiyotaki N (2010): Financial Intermediation and Credit Policy in Business Cycle Analysis. In: Woodford BM (Ed.): Handbook of Monetary Economics, chapter 11 (pp. 547-599). Elsevier.

Gertler M, Kiyotaki N, Queralto A (2011): Financial Crises, Bank Risk Exposure and Government Financial Policy. Technical report, no. 740, N.Y.U. and Princeton. 
Gomes FJ, Yaron A, Zhang L (2003): Asset Prices and Business Cycles with Costly External Finance. Review of Economic Dynamics, 6(4):767-788.

Goodfriend M, McCallum BT (2007): Banking and Interest Rates in Monetary Policy Analysis: A Quantitative Exploration. Journal of Monetary Economics, 54(5):1480-1507.

Graeve F de (2008): The External Finance Premium and the Macroeconomy: US Post-WWII Evidence. Journal of Economic Dynamics and Control, 32(11):3415-3440.

Hart O, Moore J (1994): A Theory of Debt Based on the Inalienability of Human Capital. The Quarterly Journal of Economics, 109(4):841-879.

Hlaváček M, Komárek L (2009): Housing Price Bubbles and their Determinants in the Czech Republic and its Regions. Czech National Bank, Working Papers, no. 2009/12.

Hoskin K, Nield I, Richardson J (2009): The Reserve Bank's New Liquidity Policy for Banks. Reserve Bank of New Zealand Bulletin, 72:5-18.

Chari VV, Christiano LJ, Eichenbaum M (1995): Inside Money, Outside Money and Short Term Interest Rates. NBER Working Papers, no. 5269.

Christensen I, Corrigan P, Mendicino C, Nishiyama S (2009): Consumption, Housing Collateral, and the Canadian Business Cycle. Bank of Canada, Working Papers, no. 9-26.

Christensen I, Dib A (2008): The Financial Accelerator in an Estimated New Keynesian Model. Review of Economic Dynamics, 11(1):155-178.

Christiano LJ, Eichenbaum M, Vigfusson R (2006): Assessing Structural VARs. Board of Governors of the Federal Reserve System (U.S.), International Finance Discussion Papers, no. 866.

Christiano LJ, Motto R, Rostagno M (2007): Financial Factors in Business. The Implications of Changes in Banking and Financing for the Monetary Policy Transmission Mechanism in European Central Bank. ECB.

Christiano LJ, Trabandt M, Walentin K (2007): Introducing Financial Frictions and Unemployment into a Small Open Economy Model. Sveriges Riksbank, Working Paper Series, no. 214.

Iacoviello M, Neri S (2008): Housing Market Spillovers: Evidence from an Estimated DSGE Model. American Economic Journal: Macroeconomics, 2(2):125-64.

Iacoviello M (2005): House Prices, Borrowing Constraints, and Monetary Policy in the Business Cycle. American Economic Review, 95(3):739-764.

Jakubík P (2007): Credit Risk and Stress Testing of the Banking Sector in the Czech Republic. Finance a úvěr - Czech Journal of Economics and Finance, 57(1-2):60-78.

Jermann U, Quadrini V (2009): Macroeconomic Effects of Financial Shocks. NBER Working Papers, no. 15338.

Kiyotaki N, Moore J (1997): Credit Cycles. Journal of Political Economy, 105(2):211-48.

Kocherlakota RN (2000): Creating Business Cycles through Credit Constraints. Federal Reserve Bank of Minneapolis, Quarterly Review, issue Sum, pp. 2-10.

Kumhof M, Beneš J (2011): Risky Bank Lending and Optimal Capital Adequacy Regulation. IMF Working Papers, no. 11/130.

Liu Z, Wang P, Zha T (2010): Do Credit Constraints Amplify Macroeconomic Fluctuations? Federal Reserve Bank of Atlanta, Working Paper, no. 2010-01.

Meier A, Müller GJ (2006): Fleshing Out the Monetary Transmission Mechanism-Output Composition and the Role of Financial Frictions. Journal of Money, Credit and Banking, 38(8):2099-2134.

Modigliani F, Miller MH (1958): The Cost of Capital, Corporation Finance and the Theory of Investment. The American Economic Review, 48(3):261-297.

Polanský J, Tonner J, Vašíček O, Ryšánek J (2009): Developing a Small Open DSGE Model with a Financial Sector. CNB research project, no. B2/10 (Czech National Bank). 
Reichlin P (2004): Credit, Intermediation, and the Macroeconomy: Models and Perspectives. In: Credit markets, Intermediation and the Macroeconomy. Oxford University Press, USA.

Saporta V (2009): The Role of Macroprudential Policy. Bank of England, Discussion Paper. ISSN $1754-4262$

Summers LH (1986): Some Skeptical Observations on Real Business Cycle Theory. Federal Reserve Bank of Minneapolis, Quarterly Review, issue Fall, pp. 23-27.

Tovar CE (2009): DSGE Models and Central Banks. Economics-The Open-Access. OpenAssessment E-Journal, 3(16):1-31.

Townsend R (1979): Optimal Contracts and Competitive Markets with Costly State Verification. Federal Reserve Bank of Minneapolis, Staff Report, no. 45.

Zděnek M, Molnár P, Hloušek M, Tonner J (2010): DSGE Model with Housing Market. CNB research project, no. B5/11 (Czech National Bank). 